\title{
Optimization study of blasting operations in Roşia Poieni open pit mine, Romania
}

\author{
Mihaela Toderas ${ }^{1 * \otimes}$ (1) \\ ${ }^{1}$ University of Petrosani, Petrosani, 332006, Romania \\ *Corresponding author: e-mail toderasmihaela@yahoo.com,tel.+40741501143
}

\begin{abstract}
Purpose. Drilling-blasting technology is one of the simplest and most often used techniques in open pit mining. This allows the excavation of a large volume of rock and useful mineral substance. The operation of blasting using the energy of explosives plays an important role in open pit exploitation, being also the key element of the blasting process through which a corresponding granulometry is obtained. This operation is a part of a series of interdependent operations, in the sense that each operation determines a certain result that will be an important element for the next operation that takes place in the working face. Consequently, the blasting operation with explosives should not be considered as an independent act. A global approach to the entire production technological process including blasting is required.
\end{abstract}

Methods. In the optimization study, the basic method consisted in the analysis of the blasting operations performed at the drilling diameter of $250 \mathrm{~mm}$ (blasting technology used in Roşia Poieni open pit mining) and simulation of the excavation of the same rock volume, with the optimization of the explosive charge distribution at two other drilling diameters: 200 and $150 \mathrm{~mm}$.

Findings. The main problems when shooting $250 \mathrm{~mm}$ dia holes are caused by the length of the tamping in the mineralized rock that leads to the appearance of blocks with dimensions which are maximum allowed in the crusher tank (1.2-1.3 m). That is why discontinuous loads with intermediate tamping are used - the method that successfully limits their number. In order to obtain a granulometry corresponding to the primary crushing operation, which will allow to decrease the crushing costs, it is necessary to use smaller drilling diameters, but with productivity high enough to ensure the optimal development of the extraction process.

Originality. Based on the performed study, it is recommended to use the discontinuous load, preserving the total length of the explosive charge. In the zones where the rocks have a Protodiakonov coefficient $f>6.5$, it is recommended to apply an appropriate drilling diameter $(150-200 \mathrm{~mm})$ and use the intermediate tamping at 2-3 $\mathrm{m}$ length to limit the upper stemming area to a maximum of $7 \mathrm{~m}$ (to limit or eliminate the occurrence of oversized blocks).

Practical implications. The research results will enhance the geometric and safety factors of the operation, limiting the explosion effect on the massif and the environment and reducing the total costs of the cutting operation. The cost of explosives and initiating materials can be reduced by using a smaller quantity of explosive gels in a dry environment (12-18 kg/hole), the difference in the explosive charge length being completed with AM 1.

Keywords: open pit exploitation, drilling-blasting, andesite, explosive, blasting borehole, optimization

\section{Introduction}

Quarry exploitations are characterized by a series of basic features that ensure the achievement of high production and productivity, in short terms and at low costs, materialized mainly by: practice of efficient exploitation methods; complex mechanization of production processes with the use of adequate equipment of high productivity; judicious planning and organization of works [1]-[3].Compared to the underground exploitation, the quarry exploitation of the deposits of useful mineral substances presents essential advantages that require the analysis of its application whenever possible [4]-[6]. The current stage of the exploitation development in the quarry is characterized by a series of achievements in performing the main operations in the technological flow. Thus, in high strength rocks the boreholes are generally drilled at diameters of 200-350 mm, with the use of boring machines that work according to the rotary or rotary-percussive boring system. In very hard and brittle rocks, thermal drilling is widely applied, obtaining results clearly superior to those obtained by applying the classic drilling procedures. In the field of explosives, there is an almost widespread use of explosives based on ammonium nitrate, gas-oil and slurry type muddy consistency with additions of metal powders [7]-[10].

Received: 9 February 2021. Accepted: 12 October 2021. Available online: 24 December 2021

(C) 2021. M. Toderas

Published by the Dnipro University of Technology on behalf of Mining of Mineral Deposits. ISSN 2415-3443 (Online) | ISSN 2415-3435 (Print)

This is an Open Access article distributed under the terms of the Creative Commons Attribution License (http://creativecommons.org/licenses/by/4.0/),

which permits unrestricted reuse, distribution, and reproduction in any medium, provided the original work is properly cited. 
The development of quarry exploitation of useful mineral deposits requires solution of some very important problems, related to [11]-[13]: establishing the rational limits of open pit operations; opening works, first-mining and exploitation of the quarry field; dimensioning the benches and analysing their stability; establishing the profitability of exploitation and active duration of the quarry; quarry activities management etc. In this paper, we set out to perform an optimization analysis of blasting operations in Roşia Poieni open pit, Romania.

Copper remains one of the base metals in industry, especially in electronics, although over many years and with considerable effort many countries have tried to replace it by aluminium [8], [14]-[17].

Following the feasibility studies that were carried out, the Roşia Poieni deposit was declared the largest copper and gold deposit in Romania and the second largest in Europe; its reserves representing $65 \%$ of the total quantity of copper in Romania. The main objective of the CupruMin Company activity is extraction of non-ferrous metal ores and preparation of copper ores from the Roşia Poieni deposit, with the production of copper concentrate and precious metals. The useful substances obtained are copper, gold and silver. These metals are found in the copper concentrate which is the finished product of the preparation plant; other metals not found in copper concentrate but present in copper ore may become recoverable in the future.

Other useful minerals are the resources of industrial and construction andesite near the Roşia Poieni copper ore deposit, namely Poieni andesite and limestone from Pârâul Româneasa quarry. Mining products made from these resources are: crushed stone, sieves, crushing sand, limestonerough stone. Limestone is mainly used as rockfill to increase the height of the dam in Valea Şesei tailings pond. According to the certificate of conformity issued by the Transport Research Institute-INCERTRANS, andesite products are suiTable for a wide range of constructions. The company has authorized personnel to carry out operations of loading, unloading, handling and transporting of explosive materials and certified means of road transport.

\section{Geology of Roşia Poieni deposit}

From a geological point of view, the deposit belongs to the Bucium-Roşia Montană area of the Bucium pit, where Cretaceous (Senonian) and Tertiary (Pliocene) formations are found, arranged on a crystalline foundation known as "Baia de Arieş crystalline dyke" and crossed with the volcanic products of Neogene magmatism. The deposit belongs to the alpine cycle and is included in the area of concentrations associated with Neogene volcanism, the sub-province of Apuseni Mountains and the area of "Golden Quadrangle" in Bucium-Roşia Montană district.

Within the Roşia Montană-Bucium metallogenetic district, the spaces with the densest overlap of four fracture systems (pre-tertiary and reactivated systems NV-SE, NESV, EV and Neogene N-S system) with magmatic and metallogenetic functions were created. Within these permeable and intensely divided spaces of the Precambrian crystalline foundation (Baia de Arieş series, retromorphite) and of the Eocretaceous and Neocretaceous sedimentary formations (Bucium unit), Paleocene and Miocene (75\% of the rocks total volume), Neogene eruptive products have been put in place: quartz andesites, dacites, amphibole andesites, andesitic or pyroclastic lava flows, basalt andesites, micro diorites, volcanic breccia, tectonic breccia, mixed breccia [2], [8].

The deposit is located in the sub-volcanic Fundoaia body, in the mass of micro diorites' body shaped as a vertical pillar (dome), with a height of approximately $1,200 \mathrm{~m}$ (from elevation 1030 to $-150 \mathrm{~m}$ ) and a horizontal section towards an irregular surface variable in size $(660 / 770 \mathrm{~m}$ at elevation $956 \mathrm{~m})$ and with an elliptical shape $(740 / 820 \mathrm{~m}$ at elevation $551.64 \mathrm{~m}$ ) to depth.

Porphyry copper mineralization (approximately $85 \%$ of the deposit volume) consists mainly of fine spreads, cracks, veins, and small veins $(0.002-3 \mathrm{~cm}$ thickness) arranged in the micro-diorite mass deeply affected by allochemical metamorphism, forming a well-developed stock-work. The epithermal vein mineralization (approximately $15 \%$ of the deposit volume) is located in the tectonic brecciated areas on the N-S alignments or on their support fractures. The weathering zones found within Roşia Poieni deposit (biotitic zone, sericite zone, argillaceous zone) correspond to a zone of metalliferous mineralization, controlled by the same structural and physical-chemical factors.

The crack measurements allowed to highlight the main directions of the crack planes extending to the NorthwestSoutheast, Northeast-Southwest and less often Eastwest. The systems of cracks and cooling fractures formed in the rock mass intersecting the major tectonic fractures, favoured mineralization, being generally the determining factors to control sulphides mineralization.

From a geotechnical point of view, the presence of these cracks in the rock mass leads to their partition into separate blocks, thus reducing the strength and stability of the quarry slopes. In case of dips conforming to the slope angles, planes of minimum sliding resistance are created. Also, the frequency of these cracks leads to the secondary weathering of eruptive rocks by the cumulative action of atmospheric agents in the presence of water, a phenomenon that will continuously affect the edge slopes of the quarry [8], [18]-[20]. In andesites from the deposit area, the only ways for water to enter and circulate are cracks systems and cooling crevices, and fracture areas that affect the eruptive structure. The contact areas between the two types of andesites (Poieni andesite and Fundoaia andesite) and between andesites and sedimentary rocks, are areas of strong breccia that also constitute water circulation paths to depth.

\section{Dislocation of rocks from massif using the explosives}

Explosives, as an energy source, are used in various economic sectors; this is due to the fact that their use accelerates the accomplishment of projects and facilitates the work of man [10], [21]-[23]. When extracting rocks by drillingblasting operations, the explosives are used to detach the predetermined quantities of rock from the massif. Blasting is to take place within well-defined areas and the massif around the excavation should not be affected; or if this cannot be achieved, the damage caused must be as small as possible and situated within pre-established limits [24]-[26].

\subsection{Choosing explosives used in blasting operations at Roşia Poieni}

The choice of explosive type used to perform the work is an important decision that will influence all the results obtained [18], [24]-[26]. The type of explosive corresponding to the required works is chosen taking into account the cha- 
racteristics of rocks and the type of product to be obtained on the one hand and the characteristics of the explosive on the other hand. The choice of explosives should take into account the gases resulting from blasting operations, the vibrations induced in the mass and the blast of the explosion [8], [9], [20], [27], [28].

All industrial explosives are prepared to have maximum energy and minimum toxic gases after the explosion. From the point of view of vibration and explosion blast, preference should be given to those explosives which produce a lower level of vibration and blast. In this sense, it is possible to program the explosion of different loads in the system at certain time intervals between them. The amount of energy transmitted to the rock can be estimated depending on the blast acoustic impedance.

Gel-type explosives or emulsions can be used in deposits with difficult hydrogeological conditions, even if the acous- tic impedance ratio is less than 0.8 . The choice of explosives for blasting operations can also be determined by the volume of rock to be blasted at once. High quantities of explosives are used in massive blasting operations when large volumes of rock are detached. In such cases, mechanical loading of simple explosive mixtures may be recommended, thus reducing the costs of loading and blasting per unit of rock mass extracted from the rock massif.

The choice of mining explosives also depends on the dislocation efficiency of blasting in terms of the total rock extraction. Thus, the use of cheap explosives such as ammonium nitrate and oil or explosive gels, involves the execution of large diameter holes, thus increasing drilling costs. The cost, related to all the operations in the quarry, including crushing and grinding, as well as the possibility to purchase adequate drilling equipment, determines the choice of an explosive [8], [24], [26], [29].

Table 1. The choice of explosive for different types of rocks from Roşia Poieni open pit depending on the impedance ratio

\begin{tabular}{lccccc}
\hline & & \multicolumn{4}{c}{ Rock-explosive acoustic impedance ratio } \\
\cline { 3 - 6 } $\begin{array}{c}\text { Type } \\
\text { of explosive }\end{array}$ & $\begin{array}{c}\text { Acoustic } \\
\text { impedance } \\
\text { of explosives, } \\
\mathrm{m} / \mathrm{s} \cdot \mathrm{kg} / \mathrm{m}^{3}\end{array}$ & $\begin{array}{c}\text { Acoustic impedance of rocks, } \mathrm{m} / \mathrm{s} \cdot \mathrm{kg} / \mathrm{m}^{3} \\
\text { chloritized } \\
\text { Poieni andesite } \\
(5.6-15.7) \cdot 10^{3}\end{array}$ & $\begin{array}{c}\text { Hydrothermal } \\
\text { weathered } \\
\text { Poieni andesite } \\
(5.6-15.7) \cdot 10^{3}\end{array}$ & $\begin{array}{c}\text { Silicified and } \\
\text { chloritized } \\
\text { Fundoaia andesite } \\
(5.5-9.9) \cdot 10^{3}\end{array}$ & $\begin{array}{c}\text { Hydrothermal } \\
\text { weathered } \\
\text { Fundoaia andesite } \\
(0.7-1.1) \cdot 10^{3}\end{array}$ \\
\hline Astralit & $3.1 \cdot 10^{3}$ & $1.65-4.62$ & $0.31-0.53$ & $1.62-2.91$ & $0.21-0.32$ \\
\hline Dynamite RA & $6 \cdot 10^{3}$ & $0.93-2.6$ & $0.17-0.33$ & $0.91-1.65$ & $0.12-0.18$ \\
\hline AM 1 manually loaded & $1 \cdot 10^{3}$ & $3.1-8.72$ & $0.57-4.62$ & $3.05-5.5$ & $0.39-0.61$ \\
\hline $\begin{array}{l}\text { AM 1 mechanically } \\
\text { loaded }\end{array}$ & $2.4 \cdot 10^{3}$ & $2.33-6.54$ & $0.43-0.75$ & $2.29-4.12$ & $0.29-0.41$ \\
\hline Rovex 650 & $5.8 \cdot 10^{3}$ & $9.96-2.71$ & $0.18-0.31$ & $0.95-1.71$ & $0.12-0.19$ \\
\hline Rovex 700 & $3.8 \cdot 10^{3}$ & $1.47-4.13$ & $0.27-0.47$ & $1.45-2.6$ & $0.18-0.29$ \\
\hline Rovex Extra & $4.3 \cdot 10^{3}$ & $1.30-3.65$ & $0.24-4.42$ & $1.28-2.3$ & $0.16-0.26$ \\
\hline
\end{tabular}

\subsection{Blasting techniques used in Roşia Poieni open pit}

To prepare the surface on which the open pit mining will be further developed, stripping and deforestation works were carried out in the Dealul Melciului region, between the levels of 940 and $1060 \mathrm{~m}$ and in the dumps areas. These brought about changes in the microclimate of the area: the average daily temperatures increased by $1-2^{\circ} \mathrm{C}$, the precipitation regime was affected: rains became shorter and more intense. In the open pit, there are no problems regarding accumulation of meteoric water in the bottom (level $835 \mathrm{~m}$ ); it infiltrates through microcracks to the existing underground prospecting cavities and gets evacuated through the Muşca gallery, level $770 \mathrm{~m}$.

However, in underground works, during periods of heavy rainfall, infiltration flows of over $40 \mathrm{~m}^{3} / \mathrm{h}$ were measured, which is due to the large surface of the collecting basin where the open pit extends. In order to evacuate water from the open pit at the level of $770 \mathrm{~m}$, the Muşca gallery was dug. There special works were carried out to collect the water infiltrated through the massif cracks. The drillings aimed to direct the water from the bottom of the open pit to Muşca gallery were not carried out.

\subsection{Working technology applied in the extraction operations at the Roşia Poieni open pit}

The main technological operations used in the quarry are the following: drilling boreholes with SBS-250 and Atlas Copco type drills (borehole diameter being $250 \mathrm{~mm}$, drilling speed depending on rock hardness, on average 8-30 m/hour); blasting with explosives for mining use; loading the resulting rock with EKG electric crawler excavators $\left(5\right.$ and $\left.8 \mathrm{~m}^{3}\right)$ and front loaders with a bucket capacity of 9 and $12 \mathrm{~m}^{3}$, respectively; transportation of mining mass by high capacity dump trucks 55-90 t; gathering scattered rock, cleaning the fronts, leveling the berms, cleaning the base of the slopes, pushing the waste rock on the slopes of the tailings dumps.

The existing and necessary technological equipment for the realization of the provided production capacities comprises (the basic technology is responsible for $85 \%$ of the excavations): SBS-250 and Atlas Copco drills; crawler bulldozers, various surfacing (differential excavation) equipment; excavators, high capacity front loaders; high capacity dump trucks. The working regime for the basic technological equipment in the quarry is 280 working days/year; extraction program of 16 hours/day and 6 days/week; 8 hours/shift.

The working technology includes the following phases: drilling; blasting with explosives; loading the dislocated material by electric excavators and front loaders; transportation of the material dumped from faces by high capacity dump trucks; primary crushing of ore (gyratory crusher type KKD 1500/180); transportation of ore on conveyor belts to the Dealul Piciorului deposit (route of about $3 \mathrm{~km}$ ); storage, waste dumping; auxiliary operations in the quarry. The geometrical elements of the benches according to the used loading equipment are presented in Table 2.

The general slope angle of the benches system is $25-35^{\circ}$; the minimum advance between the faces located on the same bench is $60 \mathrm{~m}$, and the advance between the faces located on different benches is minimum $100 \mathrm{~m}$ (Fig. 1). 
Table 2. Geometrical elements of the benches

\begin{tabular}{lcc}
\hline \multicolumn{1}{c}{ Element } & EKG 4-5 $\mathrm{m}^{3}$ & EKG 8, IF 10 \\
\hline Bench height, $\mathrm{m}$ & 15 & 15 \\
\hline Working berm width, $\mathrm{m}$ & 30 & 40 \\
\hline Front length, $\mathrm{m}$ & 40 & 40 \\
\hline $\begin{array}{l}\text { Maximum front slope angle, } \\
\text { degrees }\end{array}$ & 80 & 80 \\
\hline $\begin{array}{l}\text { Maximum side slope angle, } \\
\text { degrees }\end{array}$ & $65-70$ & $65-70$ \\
\hline
\end{tabular}

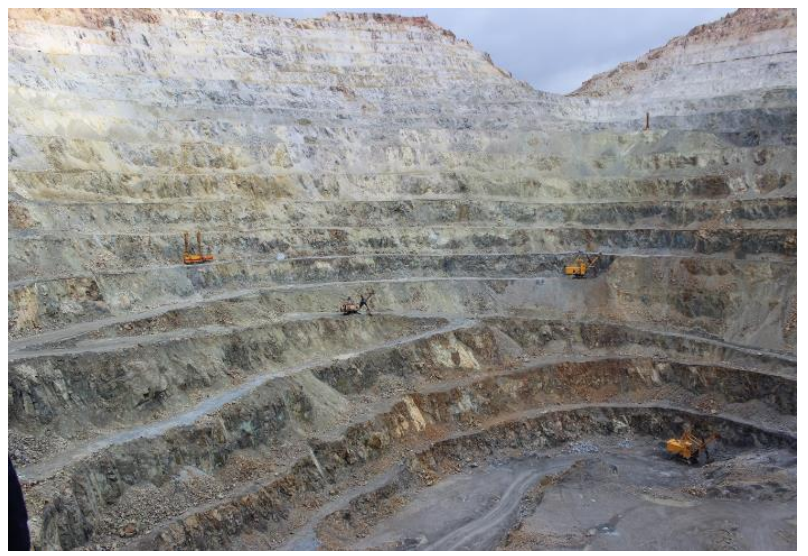

Figure 1. The advance between the faces in Rosia Poieni open pit mine

The method of blasting with explosives placed in boreholes is applied on all benches that are used for excavation. The method consists in drilling boreholes; loading boreholes with mining explosives and tamping them; connecting the loads according to the blasting scheme; conducting the explosion and checking for detonation of holes. The operation of drilling boreholes in the Roşia Poieni open pit is performed exclusively with rotary drills (SBS 250 and Atlas Copco). The parameters of the drilling network are shown in Table 3.

Table 3. The parameters of the drilling network

\begin{tabular}{lc}
\hline \multicolumn{1}{c}{ Parameter } & Value \\
\hline Bench height $h, \mathrm{~m}$ & 15 \\
\hline Borehole length $l_{g}, \mathrm{~m}$ & 17.5 \\
\hline Subdrilling length $l_{\text {sub }}, \mathrm{m}$ & 2.5 \\
\hline Strength line of hole bottom $w_{t}, \mathrm{~m}$ & 6.5 \\
\hline The distance between the boreholes $a, \mathrm{~m}$ & 6 \\
\hline The distance between the rows $b, \mathrm{~m}$ & 5 \\
\hline
\end{tabular}

The quantity of base and initiation explosives in each charged borehole is determined by the ratio of the initiating explosive to the total base charge. Depending on the quantity of explosive in each charged borehole, the tamping length is then calculated.

This tamping length must finally lead to blasting without projection and rambling effects as well as to obtaining a suitable grading. In Roşia Poieni open pit, AM 1, an explosive composed of ammonium nitrate and oil, is used as a basic explosive. At present, the loading of boreholes is done mechanically with a special mobile vehicle. The obtained values for the explosive charge in the field conditions of Roşia Poieni open pit are summarized in Table 4.

The detritus resulting from drilling holes is used as tamping. A blasting schema with delayed charges of boreholes placed in the same row of $25 \mathrm{~ms}$, respectively $42-84 \mathrm{~ms}$ between the rows of holes is used, thus obtaining an appropriate effect of crushing and dispersing the blast mining mass.
Table 4. Explosive charge for the deposit conditions in Roșia Poieni open pit

\begin{tabular}{lc}
\hline \multicolumn{1}{c}{ Parameter } & Value \\
\hline Specific explosive consumption, $\mathrm{kg} / \mathrm{m}^{3}$ & 0.8 \\
\hline Tamping length, $\mathrm{m}$ & $9-10$ \\
\hline Length of charge, $\mathrm{m}$ & $7.5-8.0$ \\
\hline Charge capacity, $\mathrm{kg} / \mathrm{m}$ & 54 \\
\hline Explosive charge in the borehole, $\mathrm{kg}$ & 400 \\
\hline Basic explosive $\mathrm{AM}-1, \mathrm{~kg}$ & 375 \\
\hline Priming explosive, $\mathrm{kg}$ & 25 \\
\hline
\end{tabular}

Loading of the blasting material resulting from the blasting operation is performed by electrically operated high-capacity excavators and high-capacity front loaders in case the electric excavators are inactive. In the face, the rock material is loaded by electrically operated excavators into high capacity (55-90 tons) dump trucks (DAC, Komatsu and Terex). The dumps tailings are transported by dump trucks (Fig. 2).

(a)

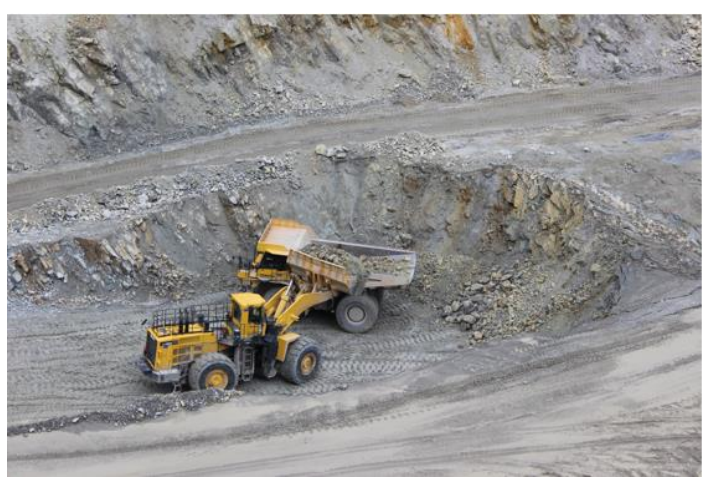

(b)

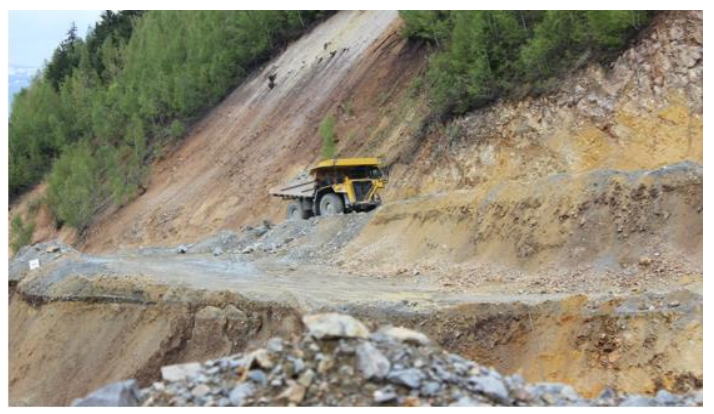

Figure 2. Loading the blasting material from the face (a) and transporting tailings to dumps (b)

Transportation is performed along the following route: face $\rightarrow$ technological road on the bench $\rightarrow$ technological road connecting the bench/dump and technological road on the platform of the dump. Depending on the available load capacity and the transportation distance from the face to the unloading points, the optimal number of dump trucks for the transportation of the required volume of mining mass is determined.

Dumping technology comprises:

- unloading the material from dump trucks on the dumping berm at a distance of 6-8 $\mathrm{m}$ from the edge of the slope depending on its stability (Fig. 3);

- pushing the material deposited on the berm of the dump bench towards the slope using surfacing equipment (crawler bulldozers type CAT D8R and DET 250M);

- leveling and compaction of dump platforms to ensure proper traffic conditions. 


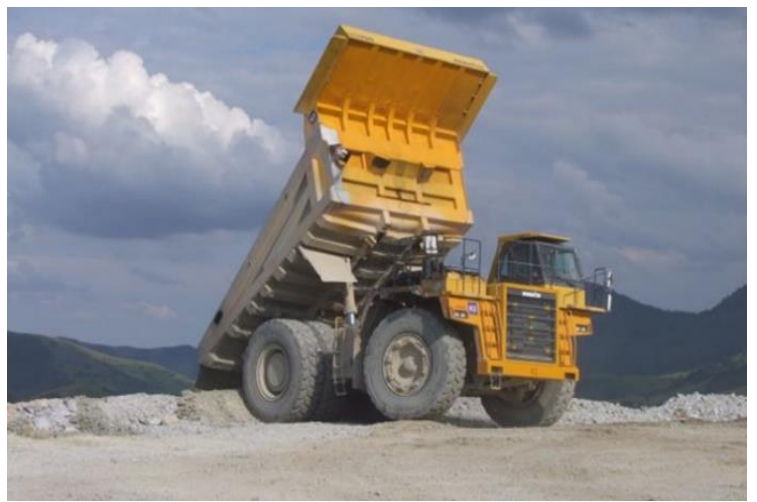

Figure 3. Unloading the material on the dump

\subsection{Exploitation method applied in Roşia Poieni open pit}

The exploitation mining activity will eventually develop the area of over 700 ha. Vertically, the exploitation began by opening the deposit in its upper part, starting from Curmătura hill $(1255 \mathrm{~m})$. Then it was discovered simultaneously on both sides. The Roşia Poieni deposit is a deposit that has a large inclination, also with a great depth extension; therefore, it was necessary to transport the tailings to external dumps. The method of exploitation with transportation of waste rocks to outer dumps is more complicated and less economical compared to the method where transportation of waste rocks is done to inland dumps which, due to the morphology of the land where the deposit is located, is the only applicable exploitation method. Also, in the case of the Roşia Poieni quarry, the volume of tailings is great and the used discontinuous transportation system has special implications for the transport flow planning.

The technical dimensional elements of the technological flow are the following:
- the Roşia Poieni deposit is extracted in descending steps with a height of $15 \mathrm{~m}$;

- rock dislocation is carried out with explosives placed in boreholes;

- the boreholes with diameters of $250 \mathrm{~mm}$, are made in a drilling network (with dimensions of $6.0 \times 5.0 \mathrm{~m}$ ) arranged in 2-3 rows, corresponding to a single blast advance of 30-50 m;

- the basic explosive used is AM 1;

- loading of mining mass demolished by blasting is done by electric excavators $\left(5-8 \mathrm{~m}^{3}\right)$ and front wheel loaders $\left(9-12 \mathrm{~m}^{3}\right)$;

- mining mass is transported by dumpers with a capacity of 55 and 90 tons;

- the ore is transported to the first crushing stage by dumpers (rotary crusher type KKD 1500/180), and from there, through a system of conveyor belts with rubber mat, it is transported to the repository of the preparation plant in Dealul Piciorului;

- the copper concentrate is obtained during the preparation processes at the preparation plant in Dealul Piciorului;

- the tailings resulting from the preparation processes are transported by gravity in the form of sterile hydromass, through steel pipes and are deposited in the Valea Şesei main tailings dam.

\section{Optimization analysis of explosive load distribution}

The Roşia Poieni deposit is extracted in descending steps with a height of $15 \mathrm{~m}$ and a slope angle $\alpha=75^{\circ}$ (Fig. 4).

Rock dislocation is carried out with explosives placed in boreholes with diameters of $250 \mathrm{~mm}$; the boreholes are drilled in a square networks arranged in two or three rows corresponding to a single blast advance of $20-30 \mathrm{~m}$. The explosive used is AM 1 and 450-gram boosters, dynamite and gel explosives cartridges are used like a priming explosive. Loading of the AM 1 explosive in the boreholes is done mechanically with the Kenworth T800 equipment.

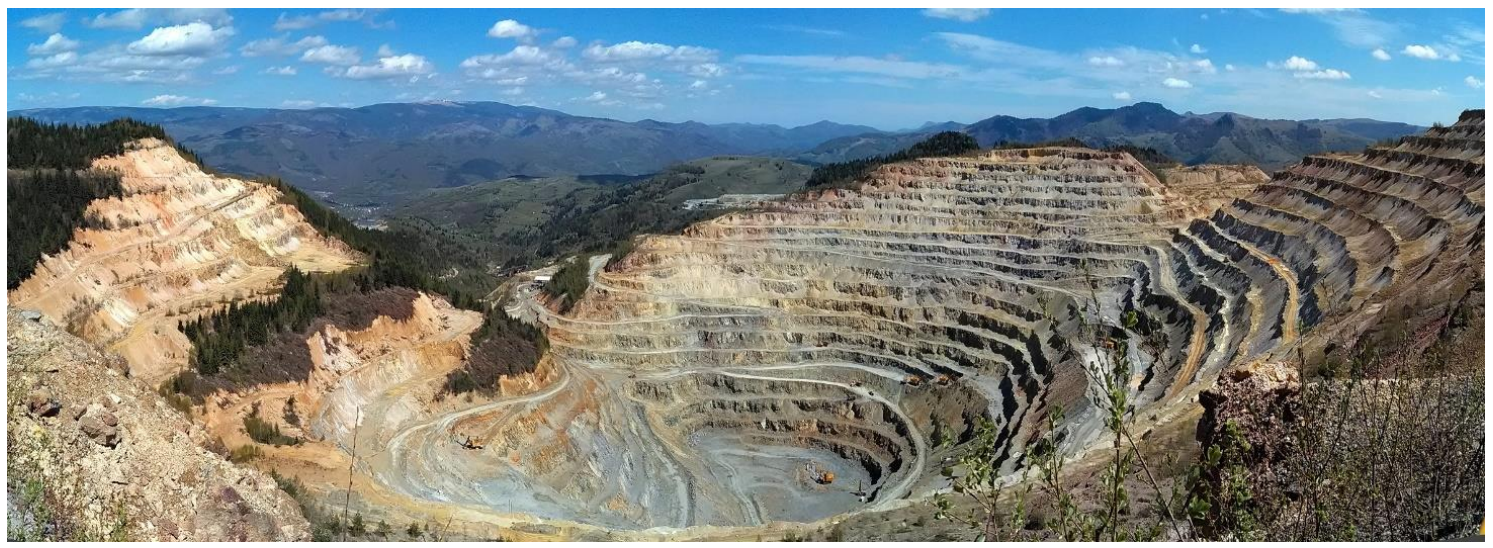

Figure 4. Overview of Rosia Poieni open pit exploitation

During the optimization study, we analysed the blasting operations performed at the drilling diameter $D=250 \mathrm{~mm}$ (blasting technology used in the Roşia Poieni quarry); at the same time, the dislocation of the same rock volume was simulated, with the optimization of the explosive load distribution for 2 other drilling diameters: $D=200$ and $D=150 \mathrm{~mm}$ respectively.

The two blasting operations were carried out during April 2019, on the level located at $970 \mathrm{~m}$ (Fig. 5), in conditions of frequently encountered hardness, namely: $5<f<7$ in the case of mineralized andesite (ore); $3<f<5$ in the case of weathered andesite (sterile).

The blasting operations computation was performed for each of the three drilling diameters: $D=250 \mathrm{~mm}$; $D=200 \mathrm{~mm} ; D=150 \mathrm{~mm}$. Table 5 shows the coefficients and parameters that were considered in the calculation. The boreholes layout is presented in Figures 6-8.

For the blasting operations, we have considered the following characteristics (basic explosive AM-1; priming: 1 booster $0.45 \mathrm{~g}$ in $12 \mathrm{~kg}$ Riogel): 
a) blasting operations performed in mineralized andesite $5<f<7$ : drilling in 2-3 rows, drilling scheme - square network; mechanized loading of holes with AM-1, as follows:

$-D=250 \mathrm{~mm}$, unit charge AM-1, $p_{1}=54 \mathrm{~kg} / \mathrm{m}$;

$-D=200 \mathrm{~mm}$, unit charge AM-1, $p_{2}=34.5 \mathrm{~kg} / \mathrm{m}$;

$-D=100 \mathrm{~mm}$, unit charge AM-1, $p_{3}=19.4 \mathrm{~kg} / \mathrm{m}$;

b) basting operations performed in weathered andesite $3<f<5$ : drilling in 2 rows; drilling scheme - square network; mechanized loading of holes with AM-1, as follows:

$-D=250 \mathrm{~mm}$, unit charge AM-1, $p_{1}=54 \mathrm{~kg} / \mathrm{m}$;

$-D=200 \mathrm{~mm}$, unit charge AM-1, $p_{2}=34.5 \mathrm{~kg} / \mathrm{m}$;

$-D=100 \mathrm{~mm}$, unit charge AM-1, $p_{3}=19.4 \mathrm{~kg} / \mathrm{m}$.

The obtained parameters from the simulation computation are shown in Table 6.

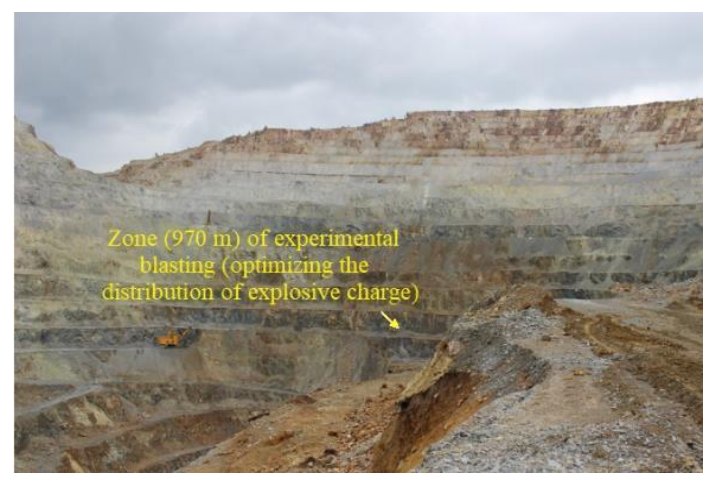

Figure 5. Experimental area of the blasting operations carried out on the exploitation bench located at the level of $970 \mathrm{~m}$

Table 5. Values of the considered parameters in the computation

\begin{tabular}{|c|c|c|c|}
\hline \multirow{2}{*}{ Considered parameter } & \multicolumn{3}{|c|}{ Value } \\
\hline & $D=250 \mathrm{~mm}$ & $D=200 \mathrm{~mm}$ & $D=150 \mathrm{~mm}$ \\
\hline \multicolumn{4}{|c|}{ Mineralized Andesite $5<f<7$ (ore) } \\
\hline Bench height & $15 \mathrm{~m}$ & $15 \mathrm{~m}$ & $15 \mathrm{~m}$ \\
\hline The surface on which the boreholes are arranged & $420 \mathrm{~m}^{2}$ & $420 \mathrm{~m}^{2}$ & $410 \mathrm{~m}^{2}$ \\
\hline Number of boreholes & 14 & 21 & 31 \\
\hline Number of connectors, pcs. & 2 pcs. & 3 pcs. & 3 pes. \\
\hline Detinel dual D25/500 ms - 24 m & 14 pes. & 21 pcs. & 31 pes. \\
\hline Detinel MS $500 \mathrm{~ms}-12 \mathrm{~m}$ & 14 pes. & 21 pcs. & 31 pes. \\
\hline Booster $450 \mathrm{~g}$ & 28 pcs. & 42 pcs. & 62 pcs. \\
\hline Electric blasting cap & 2 pcs. & 2 pcs. & 2 pcs. \\
\hline Borehole diameter & $250 \mathrm{~mm}$ & $200 \mathrm{~mm}$ & $150 \mathrm{~mm}$ \\
\hline Quantity of AM $1 / \mathrm{m}, p=\left(\pi D^{2}\right) / 4 \cdot \rho=53.9 \mathrm{~kg} / \mathrm{m}$ & $53.9 \mathrm{~kg} / \mathrm{m}$ & $34.5 \mathrm{~kg} / \mathrm{m}$ & $19.4 \mathrm{~kg} / \mathrm{m}$ \\
\hline AM 1 density at loading & \multicolumn{3}{|c|}{$\begin{array}{c}\rho=0.9 \mathrm{~kg} / \mathrm{dm}^{3} \text { at manual loading } \\
\rho=1.1 \mathrm{~kg} / \mathrm{dm}^{3} \text { at mechanized loading }\end{array}$} \\
\hline Length of charge with RIOGEL, $\mathrm{L}_{\text {inc RIOGEL }}$ & $0.5 \mathrm{~m}$ & $0.75 \mathrm{~m}$ & $1.0 \mathrm{~m}$ \\
\hline Quantity of RIOGEL/borehole & $24 \mathrm{~kg}$ & $24 \mathrm{~kg}$ & $24 \mathrm{~kg}$ \\
\hline Quantity of boosters/borehole & $0.9 \mathrm{~kg}(2$ pcs. $)$ & $0.9 \mathrm{~kg}(2$ pcs. $)$ & $0.9 \mathrm{~kg}(2 \mathrm{pcs})$. \\
\hline $\begin{array}{l}\text { The distance from the edge of the slope } \\
\text { to the first row of boreholes }\end{array}$ & $c=3 \mathrm{~m}$ & $c=3 \mathrm{~m}$ & $c=3 \mathrm{~m}$ \\
\hline Slope angle & $\alpha=75^{\circ}$ & $\alpha=75^{\circ}$ & $\alpha=75^{\circ}$ \\
\hline The rock strength coefficient after M.M. Protodiakonov & \multicolumn{3}{|c|}{$f=5-7$ for the mineralized area where the blasting took place } \\
\hline $\begin{array}{l}\text { Coefficient used to calculate the distance } \\
\text { between the boreholes in the same row }\end{array}$ & \multicolumn{3}{|c|}{$m=1.66-0.066 \times f=0.9$} \\
\hline Strength line of the bottom, $w_{t}=28 D \sqrt{\varepsilon \Delta / q m}$ & $w_{t 1}=6.8 \mathrm{~m}$ & $w_{t 1}=6.1 \mathrm{~m}$ & $w_{t 1}=4.84 \mathrm{~m}$ \\
\hline \multicolumn{4}{|c|}{ Weathered Andesite $3<f<5$ (sterile) } \\
\hline Bench height & $15 \mathrm{~m}$ & $15 \mathrm{~m}$ & $15 \mathrm{~m}$ \\
\hline The surface on which the boreholes are arranged & $420 \mathrm{~m}^{2}$ & $410 \mathrm{~m}^{2}$ & $405 \mathrm{~m}^{2}$ \\
\hline Number of boreholes & 12 & 16 & 25 \\
\hline Number of connectors, pcs. & 2 pcs. & 3 pcs. & 3 pes. \\
\hline Detinel dual 25/500 ms - $24 \mathrm{~m}$ & 12 pcs. & 16 pcs. & 25 pcs. \\
\hline Detinel MS $500 \mathrm{~ms}-12 \mathrm{~m}$ & 12 pcs. & 16 pcs. & 25 pcs. \\
\hline Booster $450 \mathrm{~g}$ & 24 pcs. & 32 pcs. & 50 pcs. \\
\hline Electric blasting cap & 2 pcs. & 2 pcs. & 2 pcs. \\
\hline Borehole diameter & $250 \mathrm{~mm}$ & $200 \mathrm{~mm}$ & $150 \mathrm{~mm}$ \\
\hline Quantity of AM $1 / \mathrm{m}, p=\left(\pi D^{2}\right) / 4 \cdot \rho=53.9 \mathrm{~kg} / \mathrm{m}$ & $53.9 \mathrm{~kg} / \mathrm{m}$ & $34.5 \mathrm{~kg} / \mathrm{m}$ & $19.4 \mathrm{~kg} / \mathrm{m}$ \\
\hline AM 1 density at loading & \multicolumn{3}{|c|}{$\begin{array}{c}\rho=0.9 \mathrm{~kg} / \mathrm{dm}^{3} \text { at manual loading } \\
\rho=1.1 \mathrm{~kg} / \mathrm{dm}^{3} \text { at mechanized loading }\end{array}$} \\
\hline Quantity of RIOGEL/borehole & $0.5 \mathrm{~m}$ & $0.75 \mathrm{~m}$ & $1.0 \mathrm{~m}$ \\
\hline Quantity of boosters/borehole & $24 \mathrm{~kg}$ & $24 \mathrm{~kg}$ & $24 \mathrm{~kg}$ \\
\hline $\begin{array}{l}\text { The distance from the edge of the slope } \\
\text { to the first row of boreholes }\end{array}$ & $0.9 \mathrm{~kg}(2 \mathrm{pcs})$. & $0.9 \mathrm{~kg}(2$ pcs. $)$ & $0.9 \mathrm{~kg}(2$ pcs. $)$ \\
\hline Slope angle & $c=3 \mathrm{~m}$ & $c=3 \mathrm{~m}$ & $c=3 \mathrm{~m}$ \\
\hline The rock strength coefficient after M.M. Protodiakonov & $\alpha=75^{\circ}$ & $\alpha=75^{\circ}$ & $\alpha=75^{\circ}$ \\
\hline $\begin{array}{l}\text { Coefficient used to calculate the distance } \\
\text { between the boreholes in the same row }\end{array}$ & \multicolumn{3}{|c|}{$f=3-5$ for the weathered area where the blasting took place } \\
\hline Quantity of RIOGEL/borehole & \multicolumn{3}{|c|}{$m=1.66-0.066 \times f=1$} \\
\hline Strength line of the bottom, $w_{t}=28 D \sqrt{\varepsilon \Delta / q m}$ & $w_{t 1}=6.8 \mathrm{~m}$ & $w_{t 1}=5.79 \mathrm{~m}$ & $w_{t 1}=4.59 \mathrm{~m}$ \\
\hline
\end{tabular}


Table 6. Computation of the blasting operations parameters

Blasting operations carried out in mineralized andesite $5<f<7$

\begin{tabular}{|c|c|c|c|c|}
\hline \multirow{2}{*}{\multicolumn{2}{|c|}{ Parameters }} & \multicolumn{3}{|c|}{ Boreholes diameter $[\mathrm{mm}]$} \\
\hline & & 250 & 200 & 150 \\
\hline \multicolumn{2}{|c|}{ Bench height, $h[\mathrm{~m}]$} & 15 & 15 & 15 \\
\hline \multicolumn{2}{|c|}{ Minimum length of tamping [m] } & 6 & 4.8 & 3.6 \\
\hline \multicolumn{2}{|c|}{ Subdrilling length, $L_{s u b}[\mathrm{~m}]$} & 2.5 & 2.4 & 1.8 \\
\hline \multicolumn{2}{|c|}{ Borehole length [m] } & 17.5 & 17.4 & 16.8 \\
\hline \multicolumn{2}{|c|}{ Adopted length of tamping [m] } & 11 & 10 & 8 \\
\hline \multicolumn{2}{|c|}{ Length of explosive charge [m] } & 6.5 & 7.4 & 8.8 \\
\hline \multicolumn{2}{|c|}{ Length of explosive charge of AM $1[\mathrm{~m}]$} & 6.0 & 6.65 & 7.8 \\
\hline \multicolumn{2}{|c|}{ Length of explosive charge in cartridge [m] } & 0.5 & 0.75 & 1.0 \\
\hline \multicolumn{2}{|c|}{ Number of drilled holes } & 14 & 21 & 31 \\
\hline \multicolumn{2}{|c|}{ Quantity of AM 1 per hole [kg/hole] } & 324 & 229 & 151 \\
\hline \multicolumn{2}{|c|}{ Quantity of porous AM 1 per hole $[\mathrm{kg} /$ hole $]$} & 305 & 216 & 142 \\
\hline \multicolumn{2}{|c|}{ Quantity of gas-oil [1/hole] } & 18.3 & 12.9 & 8.5 \\
\hline \multicolumn{2}{|c|}{ Quantity of explosive in cartridge [kg/hole] } & 24 & 24 & 24 \\
\hline \multirow{5}{*}{ Total $[\mathrm{kg}]$} & AM 1 & 4536 & 4818 & 4691 \\
\hline & Nitrate & 4264 & 4529 & 4409 \\
\hline & Gas-oil [1] & 256 & 272 & 265 \\
\hline & Riogel & 336 & 504 & 744 \\
\hline & Explosive & 4872 & 5322 & 5435 \\
\hline \multicolumn{2}{|c|}{ Hole volume $V_{g}\left[\mathrm{~m}^{3}\right]$} & 6300 & 6300 & 6138 \\
\hline \multicolumn{2}{|c|}{ Specific consumption, $q\left[\mathrm{~kg} / \mathrm{m}^{3}\right]$} & 0.773333 & 0.84475 & 0.885455 \\
\hline \multicolumn{5}{|c|}{ Blasting operations carried out in weathered andesite $3<f<5$} \\
\hline \multicolumn{2}{|c|}{ Bench height, $h[\mathrm{~m}]$} & 15.0 & 15.0 & 15.0 \\
\hline \multicolumn{2}{|c|}{ Minimum length of tamping [m] } & 6.0 & 4.8 & 3.6 \\
\hline \multicolumn{2}{|c|}{ Subdrilling length, $L_{\text {sub }}[\mathrm{m}]$} & 2.5 & 2.4 & 1.8 \\
\hline \multicolumn{2}{|c|}{ Borehole length [m] } & 17.5 & 17.4 & 16.8 \\
\hline \multicolumn{2}{|c|}{ Adopted length of tamping [m] } & 10.0 & 8.5 & 7.0 \\
\hline \multicolumn{2}{|c|}{ Length of explosive charge [m] } & 7.5 & 8.9 & 9.8 \\
\hline Length of & large of AM $1[\mathrm{~m}]$ & 7.0 & 8.15 & 8.8 \\
\hline Length of & arge in cartridge $[\mathrm{m}]$ & 0.5 & 0.75 & 1.0 \\
\hline Number of & & 12 & 16 & 25 \\
\hline Quantity o & hole [kg/hole] & 378 & 281 & 171 \\
\hline Quantity o & 11 per hole $[\mathrm{kg} / \mathrm{hole}]$ & 355 & 264 & 160 \\
\hline Quantity o & iole] & 21.3 & 15.9 & 9.6 \\
\hline Quantity o & in cartridge [kg/hole] & 24 & 24 & 24 \\
\hline & AM 1 & 4536 & 4499 & 4268 \\
\hline & Nitrate & 4264 & 4229 & 4012 \\
\hline Total [kg] & $\begin{array}{l}\text { Gas-oil [1] } \\
\end{array}$ & 256 & 254 & 241 \\
\hline & $\begin{array}{l}\text { Riogel } \\
\end{array}$ & 288 & 384 & 600 \\
\hline & Explosive & 4824 & 4883 & 4868 \\
\hline Hole volun & & 6318 & 6156 & 6075 \\
\hline Specific co & $q\left[\mathrm{~kg} / \mathrm{m}^{3}\right]$ & 0.763533 & 0.793177 & 0.801317 \\
\hline
\end{tabular}

Note: Discontinuous charge is used in the hole with intermediate tamping lengths of 2-3 m, minimum tamping length of 4-6 $\mathrm{m}$ at the hole opening, depending on the drilling diameter

The computed values of costs of explosive materials and the drilling ones, as well as the total costs for the blasting operations carried out in the two types of rocks: mineralized andesites $5<f<7$ and weathered andesites $3<f<5$, are shown in Table 7 .

\section{Results and discussions}

Following the calculations done for the two categories of rocks, we obtained the results presented in Table 8; the adopted values are shown in Table 9.

In the case of mineralized andesite, for the second row of holes, the intermediate tamping will be offset vertically from the hole by $0.5-1.0 \mathrm{~m}$. The construction of the explosive charge in the hole for the two rocks is presented in Figures 9 and 10. According to the computations, the values given in Table 9 will be adopted.
The graphical representation of the obtained results (quantities of materials, specific consumption of TNT, explosive material costs and total drilling costs) is presented in Figures 11-14.

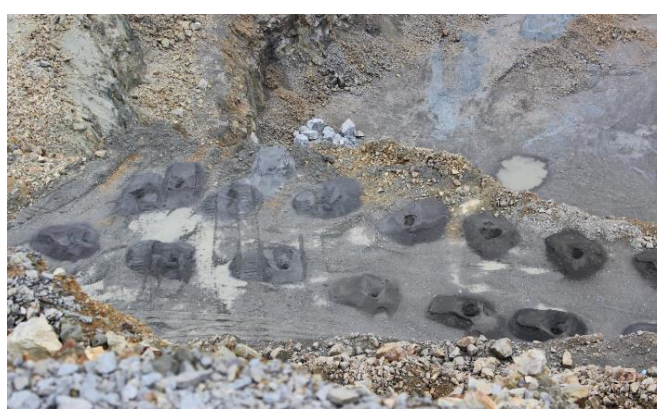

Figure 6. Boreholes in the experimental area of blasting operations 
(a)

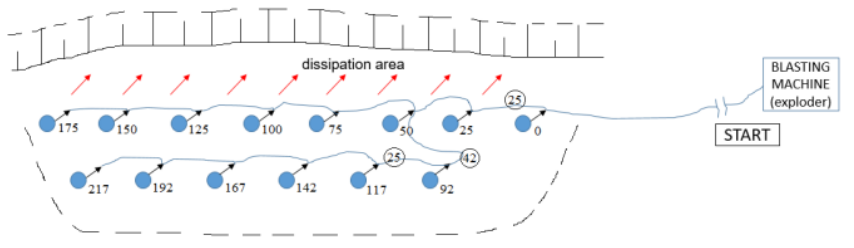

(b)

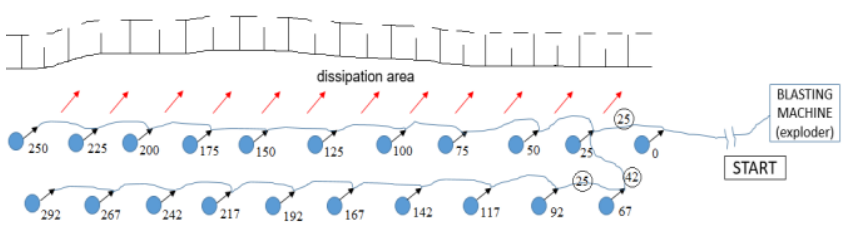

(c)

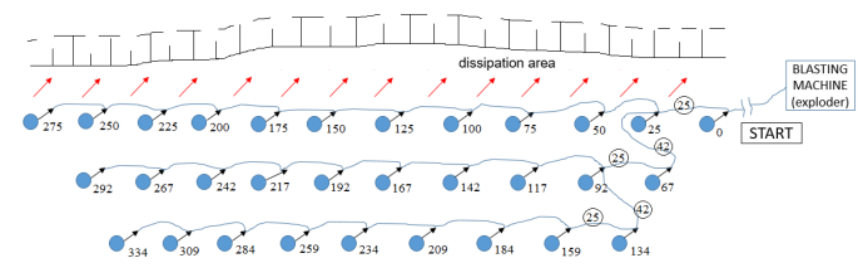

Figure 7. The boreholes layout in case of mineralized andesite $(5<f<7)$ for the three considered drilling diameters: (a) $D=250 \mathrm{~mm}, a=6 \mathrm{~m}, b=5 \mathrm{~m}, N_{g}=14$; (b) $D=200 \mathrm{~mm}$, $a=5 \mathrm{~m}, \quad b=4 \mathrm{~m}, N_{g}=21$; (c) $D=150 \mathrm{~mm}, \quad a=4 \mathrm{~m}$, $b=3.3 \mathrm{~m}, N_{g}=31$

(a)

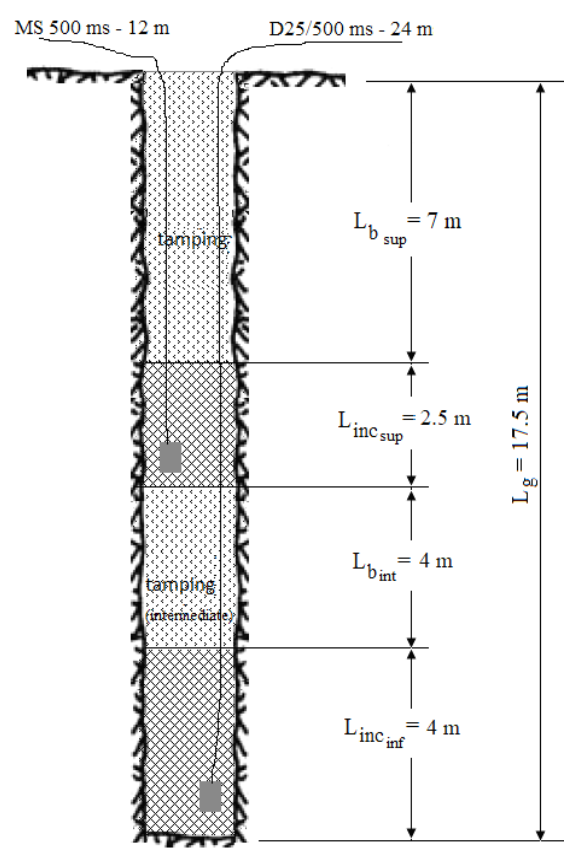

(b)

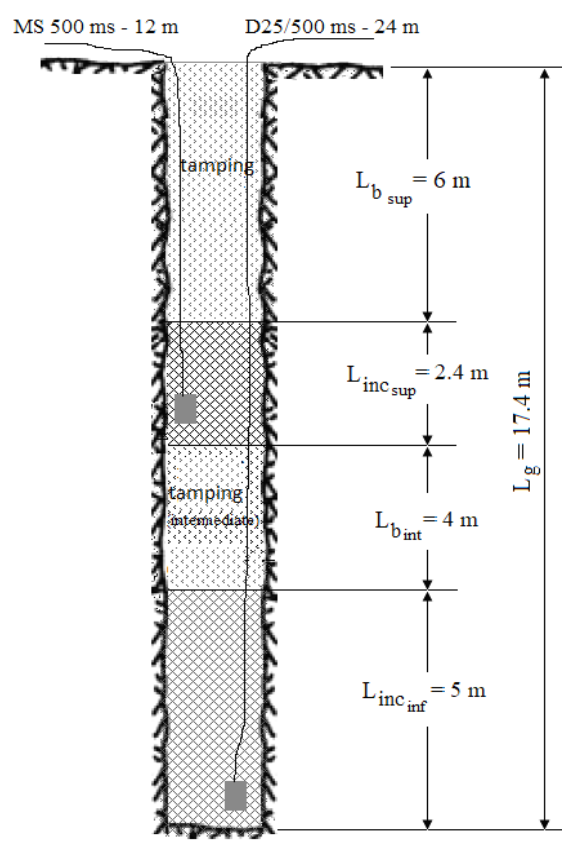

(a)

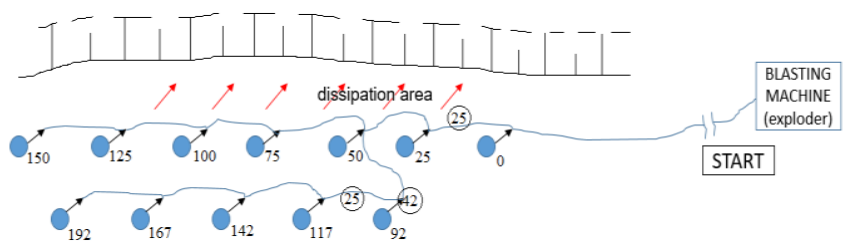

(b)

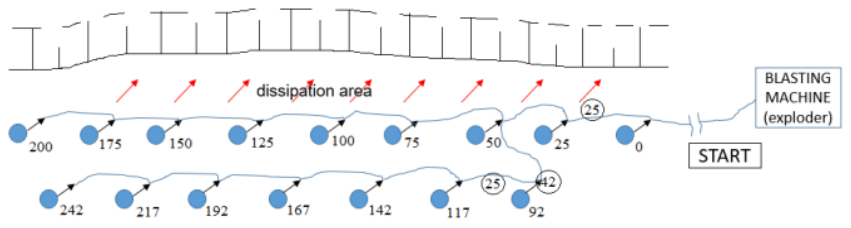

(c)

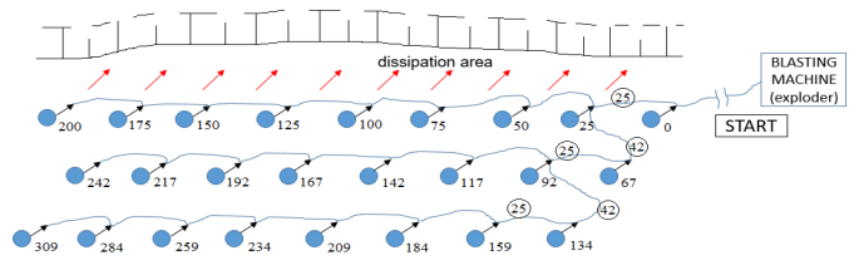

Figure 8. The boreholes layout in case of weathered andesite $(3<f<5)$ for the three considered drilling diameters: (a) $D=250 \mathrm{~mm}, a=6.5 \mathrm{~m}, b=5.4 \mathrm{~m}, \mathrm{~N}_{\mathrm{g}}=12$; (b) $D=200 \mathrm{~mm}$, $a=5.7 \mathrm{~m}, b=4.5 \mathrm{~m}, \mathrm{~N}_{\mathrm{g}}=16$; (c) $\mathrm{D}=150 \mathrm{~mm}, a=4.5 \mathrm{~m}$, $b=3.6 m, N_{g}=25$

(c)

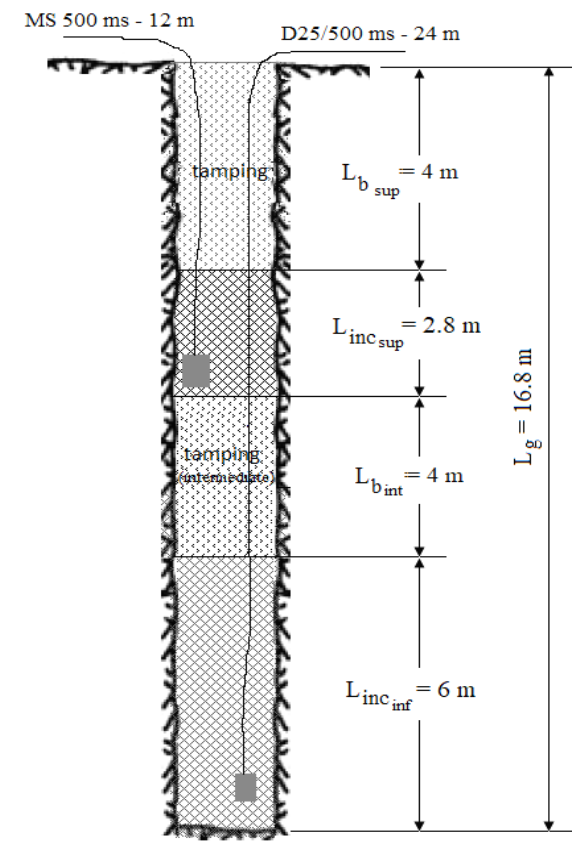

Figure 9. Construction of the explosive charge in case of mineralized andesite $5<f<7:$ (a) for diameter $D=250$ mm; (b) for diameter $D=200 \mathrm{~mm}$; (c) for diameter $D=150 \mathrm{~mm}$

The blasting operations in Roşia Poieni open pit are mainly carried out in 2 main types of rocks:

1) mineralized andesite $(5<f<7)$, containing useful rocks;

2) weathered andesite $(3<f<7)$, containing sterile rocks.

Considering the experience gained during more than 40 years of this open pit exploitation, the following drilling parameters were implemented:

1) $a=6 \mathrm{~m} ; b=5 \mathrm{~m} ; L_{g}=17.5 \mathrm{~m} ; L_{\text {sub }}=2.5 \mathrm{~m} ; w_{t}=6 \mathrm{~m}$; square drilling network;

2) $a=6.5 \mathrm{~m} ; b=5.0-5.4 \mathrm{~m} ; L_{g}=17.5 \mathrm{~m} ; L_{s u b}=2.5 \mathrm{~m}$; $w_{t}=6.5 \mathrm{~m}$; square drilling network. 
(a)

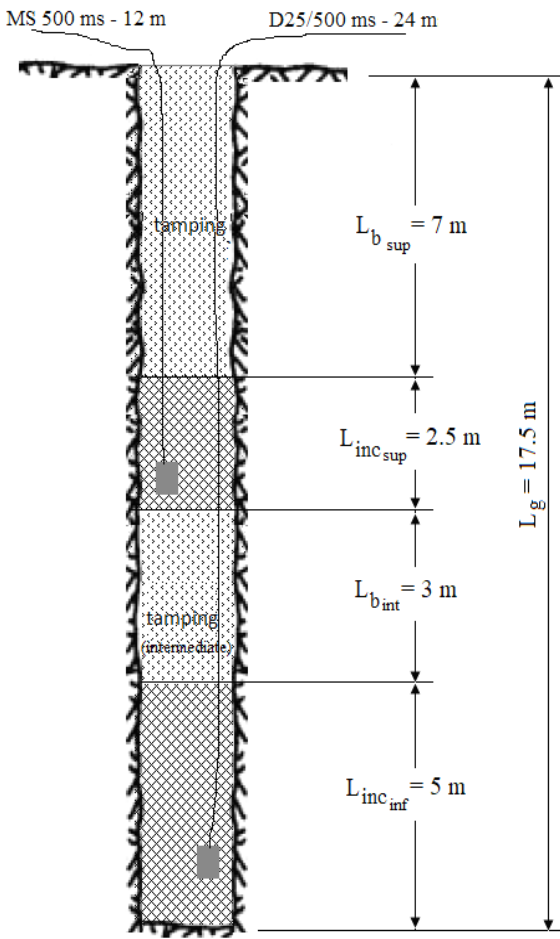

(b)

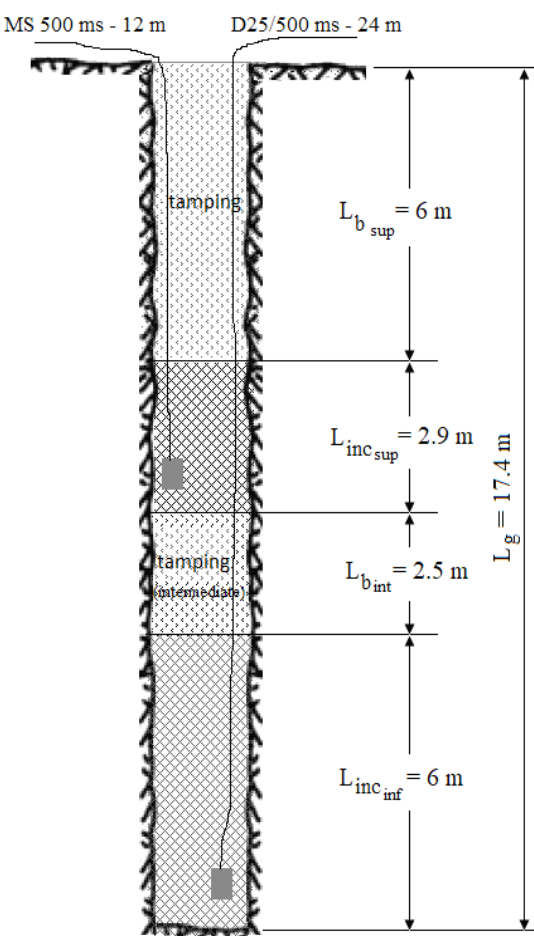

(c)

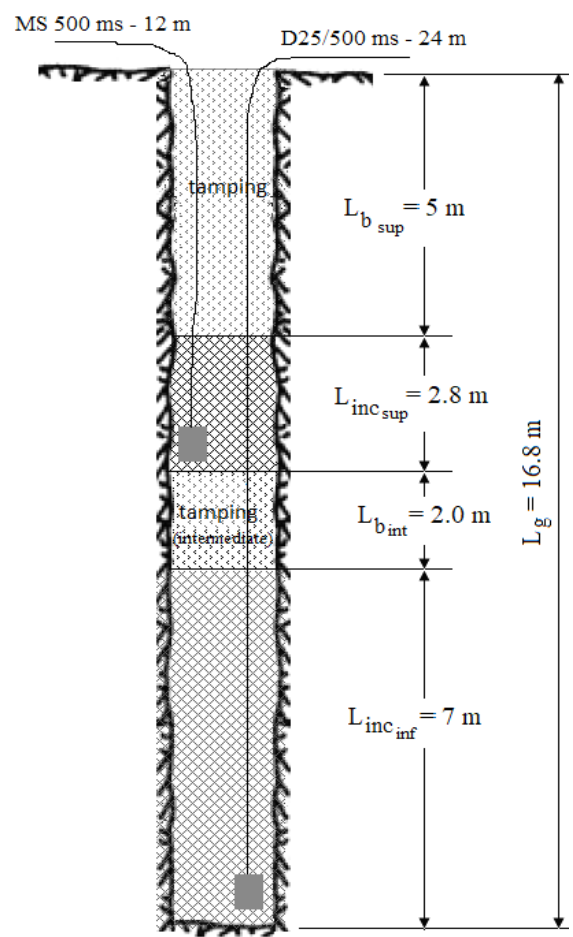

Figure 10. Construction of the explosive charge in case of weathered andesite $3<f<5$, basic explosive AM-1, priming 1 booster $0.45 \mathrm{~g}$ in $12 \mathrm{~kg}$ RIOGEL: (a) for diameter $D=250 \mathrm{~mm}, \mathrm{~L}_{b}=10 \mathrm{~m}, \mathrm{~L}_{g}=17.5 \mathrm{~m}$; (b) for diameter $\mathrm{D}=200 \mathrm{~mm}, \mathrm{Lb}_{b}=8.5 \mathrm{~m}, \mathrm{Lg}_{\mathrm{g}}=17.4 \mathrm{~m}$; (c) for diameter $D=150 \mathrm{~mm}, L_{b}=7 \mathrm{~m}, L_{g}=16.8 \mathrm{~m}$

Table 7. Costs of blasting operations for the three drilling diameters

\begin{tabular}{|c|c|c|c|c|c|c|}
\hline \multicolumn{7}{|c|}{ Mineralized andesite $5<f<7$} \\
\hline \multirow{2}{*}{ Material type } & \multicolumn{3}{|c|}{ Quantity } & \multicolumn{3}{|c|}{ Value without VAT [euro] } \\
\hline & $250 \mathrm{~mm}$ & $200 \mathrm{~mm}$ & $150 \mathrm{~mm}$ & $250 \mathrm{~mm}$ & $200 \mathrm{~mm}$ & $150 \mathrm{~mm}$ \\
\hline Porous ammonium nitrate $[\mathrm{kg}]$ & 4263.84 & 4528.85 & 4409.46 & 1705.54 & 1811.54 & 1763.79 \\
\hline Gas-oil [1] & 255.83 & 271.73 & 264.57 & 204.66 & 217.38 & 211.65 \\
\hline Riogel Troner Ø90 [kg] & 336.00 & 504.00 & 744.00 & 317.18 & 475.78 & 702.34 \\
\hline Detinel MS $500 \mathrm{~ms}-12 \mathrm{~m}[\mathrm{pcs}]$ & 14.00 & 21.00 & 31.00 & 39.26 & 58.88 & 86.92 \\
\hline Detinel D25/500 ms-24 m [pcs.] & 14.00 & 21.00 & 31.00 & 91.00 & 136.50 & 201.50 \\
\hline Connector Detinel K 42 ms/6 m [pcs.] & 2.00 & 3.00 & 3.00 & 4.18 & 6.27 & 6.27 \\
\hline Booster $0.45 \mathrm{~kg}$ [pcs.] & 28.00 & 42.00 & 62.00 & 66.64 & 99.96 & 147.56 \\
\hline Electric blasting cap [pcs.] & 2.00 & 2.00 & 2.00 & 1.68 & 1.68 & 1.68 \\
\hline Total explosives materials & & & & 2430.14 & 2807.99 & 3121.71 \\
\hline \multirow{2}{*}{ Drilling } & 5.70 & 4.47 & 3.29 & & & \\
\hline & 245 & 365.4 & 520.8 & 1396.5 & 1633.34 & 1713.43 \\
\hline Cost with explosive $\left[€ / \mathrm{m}^{3}\right]$ & & & & 0.39 & 0.45 & 0.51 \\
\hline Cost with drilling operation $\left[€ / \mathrm{m}^{3}\right]$ & & & & 0.22 & 0.26 & 0.28 \\
\hline Total cost $\left[€ / \mathrm{m}^{3}\right]$ & & & & 0.61 & 0.70 & 0.79 \\
\hline \multicolumn{7}{|c|}{ Weathered andesite $3<f<5$} \\
\hline Porous ammonium nitrate $[\mathrm{kg}]$ & 4263.84 & 4228.87 & 4011.92 & 1705.54 & 1691.55 & 1604.77 \\
\hline Gas-oil [1] & 255.83 & 253.73 & 240.72 & 204.66 & 202.99 & 192.57 \\
\hline Riogel Troner Ø90 [kg] & 288.00 & 384.00 & 600.00 & 271.87 & 362.50 & 566.40 \\
\hline Detinel MS 500 ms-12 m [pcs] & 12.00 & 16.00 & 25.00 & 33.65 & 44.86 & 70.10 \\
\hline Detinel D25/500 ms-24 m [pcs.] & 12.00 & 16.00 & 25.00 & 78.00 & 104.00 & 162.50 \\
\hline Connector Detinel K 42 ms/6 m [pcs.] & 2.00 & 3.00 & 3.00 & 4.18 & 6.27 & 6.27 \\
\hline Booster 0.45 kg [pcs.] & 24.00 & 32.00 & 50.00 & 57.12 & 76.16 & 119.00 \\
\hline Electric blasting cap [pcs.] & 2.00 & 2.00 & 2.00 & 1.68 & 1.68 & 1.68 \\
\hline Total explosives materials & & & & 2356.70 & 2490.00 & 2723.29 \\
\hline \multirow{2}{*}{ Drilling } & 5.70 & 4.47 & 3.29 & & & \\
\hline & 210.0 & 278.4 & 420.0 & 1197.0 & 1244.4 & 1381.8 \\
\hline \multicolumn{2}{|l|}{ Cost with explosive $\left[€ / \mathrm{m}^{3}\right]$} & & & 0.37 & 0.40 & 0.45 \\
\hline \multicolumn{2}{|l|}{ Cost with drilling operation $\left[€ / \mathrm{m}^{3}\right]$} & & & 0.19 & 0.20 & 0.23 \\
\hline Total cost $\left[€ / \mathrm{m}^{3}\right]$ & & & & 0.56 & 0.61 & 0.68 \\
\hline
\end{tabular}


Table 8. Values of obtained parameters for the three drilling diameters

\begin{tabular}{|c|c|c|c|}
\hline \multirow{2}{*}{ Considered parameters } & \multicolumn{3}{|c|}{ Value } \\
\hline & $D=250 \mathrm{~mm}$ & $D=200 \mathrm{~mm}$ & $D=150 \mathrm{~mm}$ \\
\hline \multicolumn{4}{|c|}{ Mineralized andesite $5<f<7$ (ore) } \\
\hline Distance between the boreholes in the same row, $a$ [m] & 6.45 & 5.49 & 4.35 \\
\hline Distance between rows of holes, $b[\mathrm{~m}]$ & 5.16 & 4.39 & 3.48 \\
\hline Subdrilling length, $L_{\text {sub }}=10 \times D[\mathrm{~m}]$ & 2.5 & 2.4 & 1.8 \\
\hline Borehole length, $L_{g}=h+l_{\text {sub }}[\mathrm{m}]$ & 17.5 & 17.4 & 16.8 \\
\hline Minimum tamping length, Lbur $\min =(20-24) \times D[\mathrm{~m}]$ & 6.0 & 4.8 & 3.6 \\
\hline Maximum length of explosive charge, Linc $\max _{\text {mam }}[\mathrm{m}$ & 11.5 & 12.6 & 13.2 \\
\hline Charge length of RIOGEL, Linc RIOGEL [m] & 0.5 & 0.75 & 1.0 \\
\hline Maximum length of AM 1 charge $L_{i n c} A M 1 \max =L_{i n c}-L_{i n c} \operatorname{RIOGEL}[\mathrm{m}]$ & 11.0 & 11.85 & 12.2 \\
\hline \multicolumn{4}{|c|}{ Weathered andesite $3<f<5$ (sterile) } \\
\hline Distance between the boreholes in the same row, $a[\mathrm{~m}]$ & 6.8 & 5.79 & 4.59 \\
\hline Distance between rows of holes, $b[\mathrm{~m}]$ & 5.44 & 4.63 & 3.67 \\
\hline Subdrilling length, $L_{\text {sub }}=10 \times D[\mathrm{~m}]$ & 2.5 & 2.4 & 1.8 \\
\hline Borehole length, $L_{g}=h+l_{\text {sub }}[\mathrm{m}]$ & 17.5 & 17.4 & 16.8 \\
\hline Minimum tamping length, $L_{b u r \min }=(20-24) \times D[\mathrm{~m}]$ & 6.0 & 4.8 & 3.6 \\
\hline Maximum length of explosive charge, Linc $\max _{\text {max }}[\mathrm{m}$ & 11.5 & 12.6 & 13.2 \\
\hline Charge length of RIOGEL, $L_{\text {inc }}$ RIOGEL $[\mathrm{m}]$ & 0.5 & 0.75 & 1.0 \\
\hline Maximum length of AM 1 charge $L_{i n c} A M 1 \mathrm{max}=L_{i n c}-L_{\text {inc }} \operatorname{RIOGEL}[\mathrm{m}]$ & 11.0 & 11.85 & 12.2 \\
\hline
\end{tabular}

Table 9. Adopted values for the three drilling diameters according to computations

\begin{tabular}{|c|c|c|c|}
\hline \multirow{2}{*}{ Considered parameters } & \multicolumn{3}{|c|}{ Adopted value } \\
\hline & $D=250 \mathrm{~mm}$ & $D=200 \mathrm{~mm}$ & $D=150 \mathrm{~mm}$ \\
\hline \multicolumn{4}{|c|}{ Mineralized andesite $5<f<7$ (ore) } \\
\hline Distance between the boreholes in the same row, $a[\mathrm{~m}]$ & 6.0 & 5.0 & 4.0 \\
\hline Distance between rows of holes, $b[\mathrm{~m}]$ & 5.0 & 4.0 & 3.3 \\
\hline Tamping length, $L_{b u r}[\mathrm{~m}]$ & 11.0 & 10.0 & 8.0 \\
\hline Tamping intermediate length, $L_{\text {bur int }}[\mathrm{m}]$ & 4.0 & 4.0 & 4.0 \\
\hline Length of upper-tamping, Lbur sup $[\mathrm{m}]$ & 7.0 & 6.0 & 4.0 \\
\hline Length of upper-explosive charge, $L_{\text {inc }}$ AM 1 sup $[\mathrm{m}]$ & 2.0 & 1.65 & 2.8 \\
\hline Length of lower-explosive charge, Linc AM 1 inf $[\mathrm{m}]$ & 4.0 & 5.0 & 5.0 \\
\hline Length of RIOGEL charge, $L_{\text {inc }}$ RIOGEL $[\mathrm{m}]$ & 0.5 & 0.75 & 1.0 \\
\hline Quantity of AM 1 per hole, $Q_{g}[\mathrm{~kg}$ AM 1/hole] & 324 & 229 & 151 \\
\hline \multicolumn{4}{|c|}{ Weathered andesite $3<f<5$ (sterile) } \\
\hline Distance between the boreholes in the same row, $a$ [m] & 6.5 & 5.7 & 4.5 \\
\hline Distance between rows of holes, $b[\mathrm{~m}]$ & 5.4 & 4.5 & 3.6 \\
\hline Tamping length, $L_{b u r}[\mathrm{~m}]$ & 10.0 & 8.5 & 7.0 \\
\hline Tamping intermediate length, $L_{\text {bur int }}[\mathrm{m}]$ & 3.0 & 2.5 & 2.0 \\
\hline Length of upper-tamping, $L_{\text {bur sup }}[\mathrm{m}]$ & 7.0 & 6.0 & 5.0 \\
\hline Length of upper-explosive charge, Linc $_{\text {AM } 1 \text { sup }}[\mathrm{m}]$ & 2.0 & 2.15 & 2.8 \\
\hline Length of lower-explosive charge, $L_{\text {inc }}$ AM 1 inf $[\mathrm{m}]$ & 5.0 & 6.0 & 6.0 \\
\hline Length of RIOGEL charge, Linc RIOGEL [m] & 0.5 & 0.75 & 1.0 \\
\hline Quantity of AM 1 per hole, $Q_{g}[\mathrm{~kg}$ AM 1/hole] & 378 & 281 & 171 \\
\hline
\end{tabular}

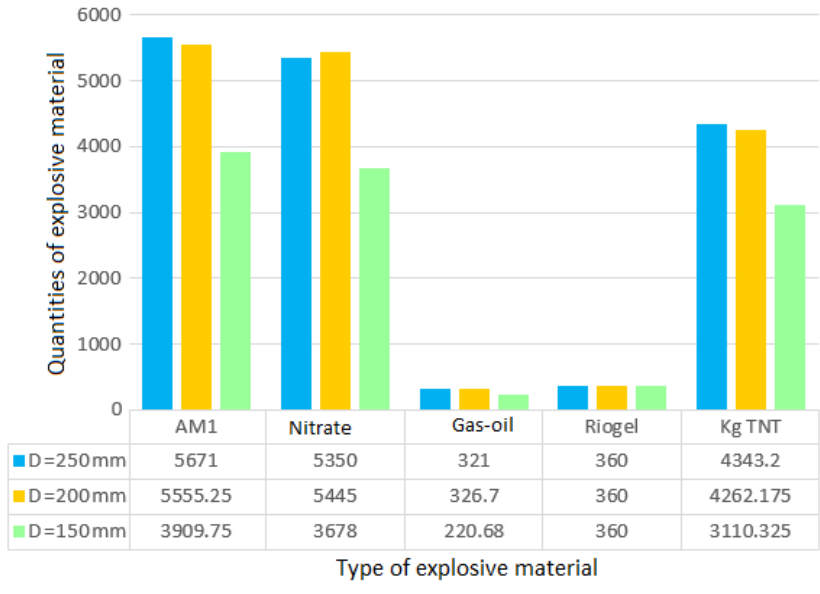

Figure 11. Variation of explosive material quantities

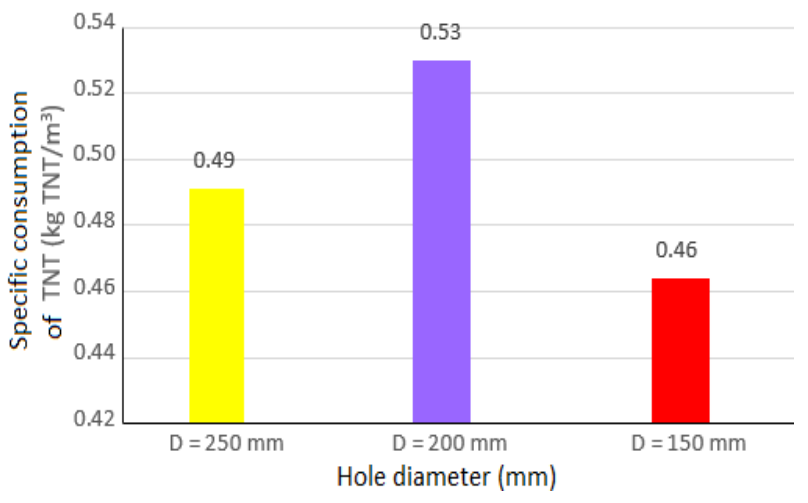

Figure 12. Variation of specific consumption of TNT (q, kg $T N T / m^{3}$ ) depending on the hole diameters 
(a)

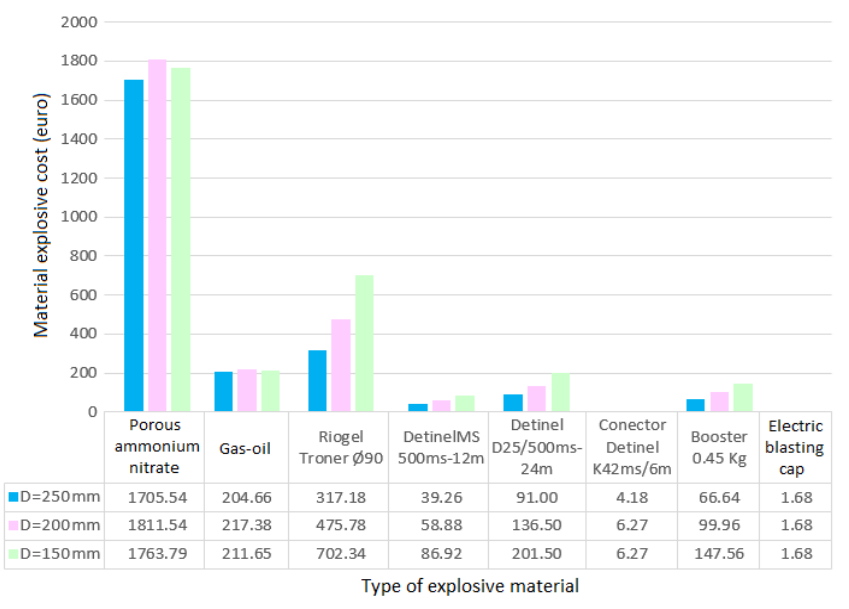

(b)

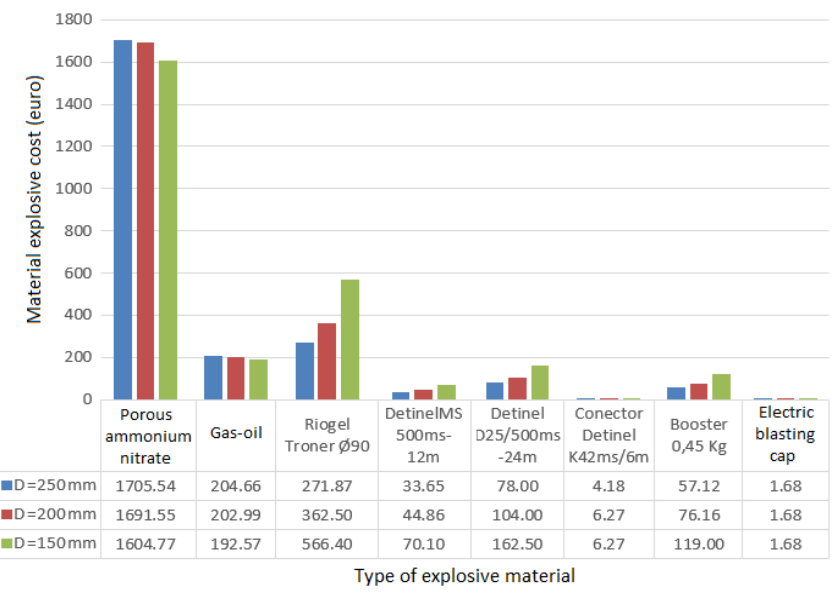

(c)

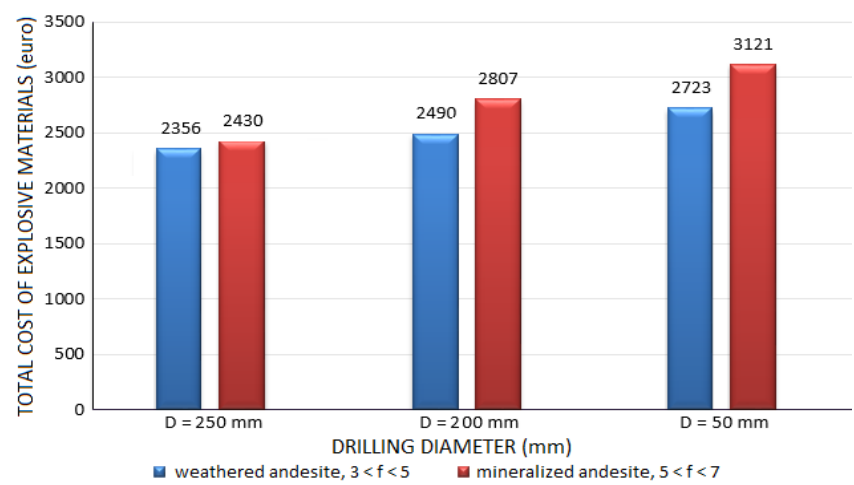

Figure 13. Cost of explosive material depending on the drilling diameter and rock type (in euro, without VAT): (a) for mineralized andesite $5<f<7$; (b) for weathered andesite $3<f<5$; (c) total costs of explosive materials

The main problems of blas-ting holes with a diameter of $250 \mathrm{~mm}$ are caused by the length of the tamping in the mineralized rock, which leads to the appearance of blocks with dimensions that are close to the maximum allowed in the crusher tank (1.2-1.3 m). This is the reason why discontinuous loads with intermediate borehole are used, a method that successfully decreases the number of such rock blocks.

In order to obtain an appropriate granulometry in the primary crushing operation and decrease the crushing costs, it is necessary to use smaller drilling diameters, but with productivity high enough to ensure the optimal development of the extraction process. In this sense, it is proposed to use a diameter of $200 \mathrm{~mm}$ for drilling. It can be easily implemented at minimal costs, by purchasing a column and drilling bits of this diameter. The bits can be mounted on the provided Atlas Copco drilling equipment.

(a)

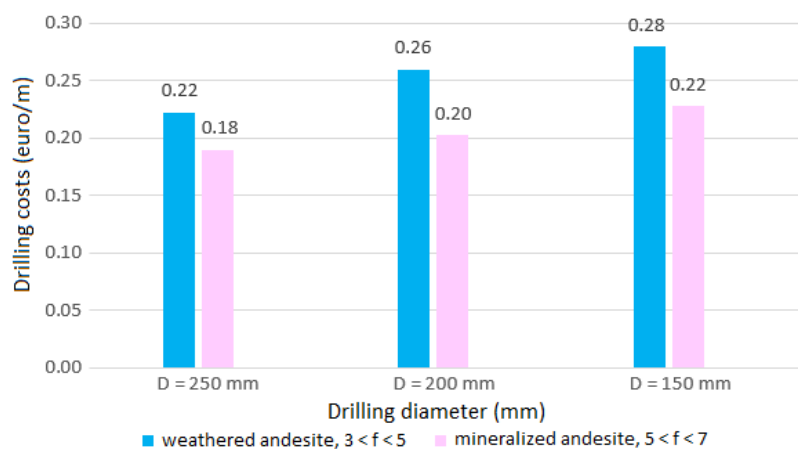

(b)

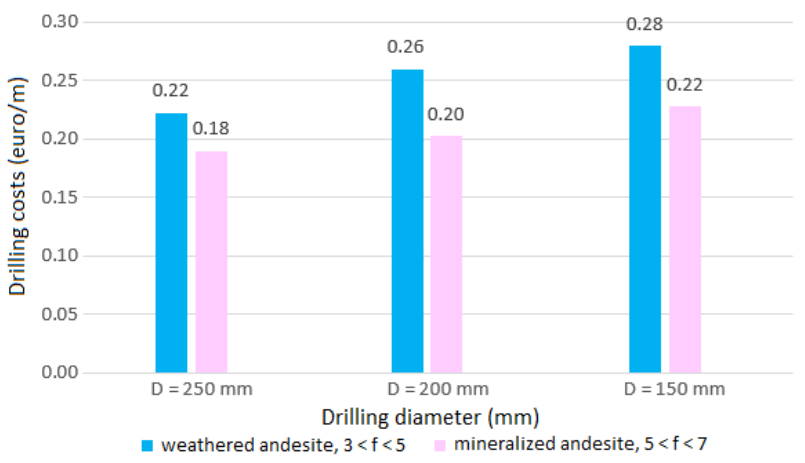

Figure 14. Drilling operations: (a) drilled linear meters; (b) total costs of drilling operation.

At the same time, it is proposed to purchase drilling equipment with a diameter of $150 \mathrm{~mm}$ for the mineralized rock, but this involves higher costs.

Analyzing the costs of explosive and initiation materials, for the excavated weathered andesite volume of $6000 \mathrm{~m}^{3}$, a minimum acceptable variation is observed:

- D250-D200 = 133.4 euro;

- and a higher value for D250-D150 $=366.6$ euro.

For mineralized andesite the same differences are true:

- D250-D200 = 378 euro;

$-\mathrm{D} 250-\mathrm{D} 150=691.6$ euro.

These differences in value for explosives and priming materials can be reduced by using a smaller amount of explosive gels $(12-18 \mathrm{~kg} / \mathrm{hole})$ in a dry environment, the difference in length of the explosive charge being completed with AM 1.

Drilling costs are as follows:

- D250-D200 = 47.4 euro; D250-D150 = 184.8 euro for weathered andesite;

- D250-D200 = 236.8 euro; D250-D150 = 317 euro for mineralized andesite.

Total cost with rock dislocation (euro, without VAT) is:

- weathered andesite $(3<f<5)$;

$-D(\mathrm{~mm}) \quad 250 \quad 200 \quad 150$;

$\begin{array}{llll}- \text { Euro } / \mathrm{m}^{3} & 0.56 & 0.61 & 0.68\end{array}$

- mineralized andesite $(5<f<7)$;

$-D(\mathrm{~mm}) \quad 250 \quad 200 \quad 150$;

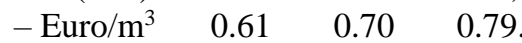


It can be noted that the total costs increase if smaller drilling diameters are used, additional costs arising mainly due to the drilling operation.

\section{Conclusions}

The rocks from quarry slopes represent different degrees and types of hydrothermal weathering. In the collected samples from the upper benches of the quarry, the processes of silicification and kaolinization predominate, while in the middle benches of the quarry the processes of limonotization are dominant.

Approximately $63 \%$ of the existing cracks in massif are represented by the so-called initial cracks to which the cracks caused by the blasting operations are added.

It is proposed to use a diameter of $200 \mathrm{~mm}$ for drilling holes. The benefits of using a drilling diameter of $200 \mathrm{~mm}$ are: limiting pieces of rock larger than $1000 \mathrm{~mm}$ resulting from the blasting operation, which leads to reduced crushing time, lower electricity consumption, control of blockages when emptying dump trucks and increasing hourly productivity of the KKD type crusher; efficient use of the explosive in the drill hole by increasing the length of the explosive column; reduction of the seismic wave at detonation due to the decrease in the amount of explosive in each hole by about $100 \mathrm{~kg}$; reducing the scattering area (dispersion) and the degree of cracking after blasting; protection of the geometric and safety elements of the benches in exploitation (transport berm, safety berm, slope angle).

\section{Acknowledgements}

This paper was elaborated following a theoretical and practical study on the blasting operations in CupruMin SA, Rosia Poieni open pit. I would like to thank Mr. Sorin Haiduc, mining engineer with CupruMin SA, for his help given in following the blasting operations in the Rosia Poieni open pit mine for a period of approximately three weeks and the interpretation of the results obtained practically and from the simulation.

\section{References}

[1] Langefors, U., \& Kihlstrom, B. (1963). The modern technics of rock blasting. New York, United States: John Wiley.

[2] Böyte, A., \& Zlăgnean, F. (1998). Stability of slopes made of hard rocks. Deva, Romania: Infomin Publishing House.

[3] Gabolde, G., \& Nguyen, J.-P. (1999). Drilling data handbook. Paris, France: Editions Technip.

[4] Adam, T., Bourgoyne, Jr., Martin, E., Chenevert, K.K., Millheim, F.S., \& Young, Jr. (2007). Applied drilling Engineering. London, United Kingdom: Society of Petroleum Engineers.

[5] Hartman, H.L., \& Mutmansky, J.M. (2002). Introductory mining engineering. New York, United States: John Wiley \& Sons.

[6] Aler, J., Du Mouza, J., \& Arnould, M. (1995). Measurement of the fragmentation efficiency of rock mass blasting and its mining applications. International Journal of Rock Mechanics and Mining Sciences \& Geomechanics Abstracts, 33(2), 125-139 https://doi.org/10.1016/01489062(95)00054-2

[7] Cook, M.A. (1974). The science of industrial explosives. Salt Lake City, United States: IRECO Chemicals.
[8] Fodor, D. (2008). Open pit exploitation of useful minerals substances and rock deposits. Deva, Romania: Corvin Publishing House.

[9] Tat, S., Zaporojan, M., \& Fissgus, M. (1985). Explosives and blasting technique in industry. Bucureşti, Romania: Technical Publishing House.

[10] Hamdi, E., \& Du Mouza, J. (2005). Methodology for rock mass characterisation and classification to improve blast results. International Journal of Rock Mechanics and Mining Sciences, 42(2), 177-194. https://doi.org/10.1016/j.ijrmms.2004.07.005

[11] Sen, G.C. (1995). Blasting technology for mining and civil engineers. Sydney, Australia: University of New South Wales Press.

[12] Zare, S., \& Bruland, A. (2007). Progress of drill and blast tunnelling efficiency with relation to excavation time and costs. Underground Space - the $4^{\text {th }}$ Dimension of Metropolises. London, United Kingdom: Taylor \& Francis Group.

[13] Andrievsky, A.P., \& Akhpashev, B.A. (2017). Improvement of rock fragmentation by distributed charge blasting. Journal of Mining Science, (53), 253-258. https://doi.org/10.1134/S1062739117022080

[14] Persson, P.A., Holmberg, R., \& Lee, J. (2000). Rock blasting and explosives engineering. New York, United States: CRC Press.

[15] Fleurisson, J-A. (2001). Structures géologiques et stabilité des pentes dans les massifs rocheux: Description, analyse et modélisation. Revue Française de Géotechnique, (95/96), 103-116. https://doi.org/10.1051/geotech/2001095103

[16] Luz-Deinny, C.H. (2006). Optimisation des tirs à l'explosif et de la chaîne de production dans les carrières de granulats, application à la carrière Hélary de Ruvernison (Morlaix, France). Paris, France: ENSMP-CGI, CESECO.

[17] Hustrulid, W. (1999). Blasting principles for open pit mining. Volume 2: Theoretical Foundations. Rotterdam, The Netherlands: Balkema.

[18] Mertuszka, P., Szumny, M., Fulawka, K., \& Nikolov, S. (2020). Field evaluation of mine blasting efficiency. SWS Journal of Earth and Planetary Sciences, (2), 1-16. https://doi.org/10.35603/eps2020/issue2.01

[19] Bitimbaev, M.Z., Krupnik, L.A., Aben, E.K., \& Aben, K.K. (2017). Adjustment of backfill composition for mineral mining under open pit bottom. Gornyi Zhurnal, (2), 57-61. https://doi.org/10.17580/gzh.2017.02.10

[20] Toderaş, M. (2002). The effect of the explosion on the environment. Deva, Romania: Bibliofor Publishing House.

[21] Konya, C.J., \& Walter, E.J. (1991). Rock blasting and overbreak control. No. FHWA-HI-92-001. Washington, United States: Federal Highway Administration.

[22] Onyelowe, K.C., Bui Van, D., Orji, F., Nguyen Van, M., Igboayaka, C., \& Ugwuanyi, H. (2018). Exploring rock by blasting with gunpowder as explosive, aggregate production and quarry dust utilization for construction purposes. Electronic Journal of Geotechnical Engineering, (23), 447-456.

[23] Yassien, M.A., Sayed, M.A., Boghdady, G.Y., Ali, M.A., \& Mohamed, A.S. (2020). Experimental research into the effect of some operation factors and rock properties on the rate of penetration. Mining of Mineral Deposits, 14(1), 36-43. https://doi.org/10.33271/mining14.01.036

[24] Da Gamma, D., \& Jimeno, C. (1993). Rock fragmentation control for blasting cost minimisation and environmental impact abatement. Proceedings of the $4^{\text {th }}$ International Symposium on Rock Fragmentation by Blasting. Vienna, Austria: Balkema.

[25] Bhandari, S. (1997). Engineering rock blasting operations. Rotterdam, The Netherlands: Brookfield.

[26] Kılıç, A.M., Yasar, E., Erdogan, Y., \& Ranjith, P.G. (2009). Influence of rock mass properties on blasting effciency. Scientific Research and Essays, (4), 1213-1224.

[27] Krasnovskii, A.A., Mirenkov, V.E., \& Shutov, V.A. (2006). Studies on fracture of rock blocks. Journal of Mining Science, (42), 105-112. https://doi.org/10.1007/s10913-006-0036-5

[28] Adebayo, B., \& Umeh, E.C. (2007). Influence of some rock properties on blasting performance: A case study. Journal of Engineering and Applied Sciences, (2), 41-44.

[29] Thornton, D., Kanchibolta, S., \& Brunton, I. (2002). Modelling the impact and blast design variation on blast fragmentation. International Journal for Blasting and Fragmentation, 6(2), 169-188. https://doi.org/10.1076/frag.6.2.169.8663

\section{Оптимізація вибухових робіт у кар'єрі Рошия Посні, Румунія}

\section{М. Тодерас}

Мета. Дослідження ефективності ведення вибухових робіт для оптимізації їх параметрів у кар'єрі Рошия Поєні, Румунія.

Методика. В якості основного методу оптимізації був використаний аналіз вибухових робіт, що виконувалися при діаметрі буріння 250 мм (технологія, що застосовується при розробці кар'єру Рошия Поєні) та моделювання виймання того ж обсягу породи 3 оптимізацією розподілу заряду вибухової речовини при двох інших діаметрах буріння: 200 і 150 мм. 
Результати. Встановлено, що основні проблеми при вибуху заряду у свердловинах діаметром 250 мм викликані довжиною забійки у мінералізованій породі, що призводить до появи блоків з розмірами максимально допустимими у резервуарі дробарки (1.2-1.3 м). Тому застосовується розосереджена зарядка з проміжною забійкою, що успішно зменшує кількість таких блоків. Для отримання блочності, що відповідає операції первинного дроблення, яка дозволяє зменшити витрати на подрібнення, необхідно використовувати менші діаметри буріння, але з такою продуктивністю, яка може забезпечити оптимальний процес вилучення породи. Рекомендується використовувати розосереджену забійку, зберігаючи загальну довжину заряду.

Наукова новизна. Експериментально виявлено, що при коефіцієнті міцності за шкалою Протодьяконова $f>6.5$ рекомендується перейти на відповідний діаметр буріння (150-200 мм) і використовувати проміжну забійку на довжині 2-3 м, щоб обмежити верхню зону забивання до 7 м ( для обмеження або недопущення утворення негабаритних блоків).

Практична значимість. Результати досліджень будуть сприяти оптимізації геометричних параметрів та безпеки проведення вибухових робіт, дозволять зменшити вплив вибуху на масив і навколишнє середовище і знизити загальні витрати на дроблення породи. Витрати на придбання вибухових речовин і засобів ініціювання можуть бути зменшені за рахунок використання меншої кількості вибухових гелів для сухого середовища (12-18 кг/свердловину), а різниця в довжині заряду вибухової речовини може бути компенсована за рахунок АМ 1.

Ключові слова: розробка кар'єру, буровибухові роботи, андезит, вибухова речовина, вибухова свердловина, оптимізачія

\section{Оптимизация взрывных работ в карьере Рошия Поени, Румыния}

\section{М. Тодерас}

Цель. Исследование эффективности ведения взрывных работ для оптимизации их параметров в карьере Рошия Поени, Румыния.

Методика. В качестве основного метода оптимизации был использован анализ взрывных работ, выполняемых при диаметре бурения 250 мм (технология, применяемая при разработке карьера Рошия Поени) и моделирование выемки того же объема породы с оптимизацией распределения заряда взрывных веществ при двух других диаметрах бурения: 200 и 150 мм.

Результаты. Установлено, что основные проблемы при взрыве заряда в скважинах диаметром 250 мм вызваны длиной забойки в минерализованной породе, что приводит к появлению блоков с размерами максимально допустимыми в резервуаре дробилки (1.2-1.3 м). Поэтому применяется рассредоточенная зарядка с промежуточной забойкой, что успешно уменьшает количество таких блоков. Для получения блочности, соответствующей операции первичного дробления, которая позволяет уменьшить затраты на измельчение, необходимо использовать меньшие диаметры бурения, но с такой производительностью, которая может обеспечить оптимальный процесс извлечения породы. Рекомендуется использовать рассредоточенную забойку, сохраняя общую длину заряда.

Научная новизна. Экспериментально выявлено, что при коэффициенте крепости по шкале Протодьяконова $f>6.5$ рекомендуется перейти на соответствующий диаметр бурения (150-200 мм) и использовать промежуточную забойку на длине 2-3 м, чтобы ограничить верхнюю зону забивки до 7 м (для ограничения или недопущения образования негабаритных блоков).

Практическая значимость. Результаты исследований будут способствовать оптимизации геометрических параметров и безопасности проведения взрывных работ, позволят уменьшить воздействие взрыва на массив и окружающую среду и снизить общие затраты на дробление породы. Затраты на приобретение взрывчатых веществ и средств инициирования могут быть уменьшены за счет использования меньшего количества взрывчатых гелей для сухой среды (12-18 кг/скважину), а разница в длине заряда взрывчатого вещества может быть компенсирована за счет АМ 1.

Ключевые слова: разработка карьера, буровзрывные работы, андезит, взрывчатое вещество, взрывная скважина, оптимизация 